\title{
ПІДВИЩЕННЯ КОМПЕТЕНЦІЙ ПОЛІЦЕЙСЬКИХ У СФЕРІ ЕЛЕКТРОННОї ІНФОРМАЦІї
}

\author{
Білоконь Д. С., Пишна А. Г.
}

Стаття присвячена питанням використання відкритих джерел інформації у підготовці здобувачів вищої освіти за галузями знань 08 «Право» та 26 «Цивільна безпека», зокрема під час викладання навчальних дисциплін: «нфформаційні технології», «Інформаційне забезпечення професійної діяльності», "Аналіз інформації з відкритих джерел", "Сучасні інформаційні технології», «Інформаційно-аналітичне забезпечення правоохоронної діяльності». Проаналізовано зміни за останні 4 роки в освітній програмі підготовки здобувачів вищої освіти (поліцейських) за спеціальністю 081 «Право» Одеського державного університету внутрішніх справ, які стосуються набуття здобувачами вищої освіти навичок використання інформаційних і комунікаційних технологій, що є складником загальної компетентності. Зауважено, що компетентність здатність до пошуку, оброблення й аналізу інформації з різних джерел у системі навчання здобувачів вищої освіти (поліцейських) постійно змінюється, тому потребує від викладача і здобувача освіти постійного саморозвитку. Проведено порівняльний аналіз найбільш поширених чат-ботів у месенджері Telegram як джерел оперативно значущої інформації для правоохоронців із метою виявлення потенціалу їх використання в навчальному процесі. Рекомендовано всім закладам вищої освіти зі специфічними умовами навчання, які здійснюють підготовку поліцейських, ввести в робочу навчальну програму дисципліни «Інформаційні технології тему «Застосування поліцейськими чат-ботів у месенджері Telegram", під час викладання якої використовувати такі чат-боти, як@OpenDataUABot, @info_baza_bot, @ temp_mail_bot, @tavk_bot, @HowToFind_bot, @storebot; @get_kontakt_bot, @mailsearchbot; @whoisdombot, @ smart_searchbot, що дасть змогу створити умови для більш якісного та продуктивного розуміння здобувачами вищої освіти процесів створення, функціонування та використання чат-ботів для вирішення прикладних задач, а вибір чат-ботів для останніх обмежити виключно метою та завданнями, які ставить керівництво правоохоронних органів перед майбутніми фахівцями.

Ключові слова: електронна інформація, інформаційні технології, чат-бот, підготовка поліцейських, відкриті джерела інформації, компетентHicmb.
Bilokon D. S., Pyshna A. H. Improving police officers' competencies in the field of electronic information

The article is devoted to the use of open sources of information in the training of higher education in the fields of knowledge 08 "Law" and 26 "Civil Security", in particular during the teaching of disciplines: "Information Technology", "Information Support of Professional Activities", "Analysis of Information from Open Sources", "Modern Information Technology", "Information and Analytical Support of Law Enforcement". We analyzed changes over the last 4 years in the educational program of higher education (police) in the specialty 081 "Law" of Odesa State University of Internal Affairs, which relate to the acquisition of higher education skills in the use of information and communication technologies, which is part of general competence. It is noted that the ability to search, process and analyze information from various sources in the system of education of higher education (police) is constantly changing, so it requires from the teacher and the student of constant self-development. A comparative analysis of the most common chatbots in the Telegram messenger as a source of operationally relevant information for law enforcement officers in order to identify the potential of their use in the educational process. It is recommended that all higher education institutions with specific training conditions that train police officers introduce the topic "Use of police chatbots in Telegram messenger" in the work curriculum of the discipline "Information Technology", during the teaching of which to use chatbots such as @OpenDataUABot, @info_baza_bot, @temp_mail_bot, tavk_bot, @HowToFind_bot, @storebot; @get_contact_bot, @mailsearchbot; @whoisdombot, @smart_searchbot, which will create conditions for better and more productive understanding of higher education students of the creation, operation and use of chatbots to solve applications, and the choice of chatbots for the latter to limit only the purpose and objectives set by management law enforcement agencies to future professionals.

Key words: electronic information, information technologies, chatbot, police training, open sources of information, competence. 
Постановка проблеми. Якісна освіта $\epsilon$ найважливішим питанням розвитку суспільства, а практично орієнтована професійна підготовка майбутніх поліцейських у сфері використання інформаційних технологій нині вкрай важлива для забезпечення високого рівня безпеки у суспільстві, належної протидії злочинності.

Зараз українське суспільство стає все більше діджиталізованим, не в далекому майбутньому вже впровадження електронного голосування та поширення єдиного порталу державних послуг «Дія».

Поряд з цим прямо пропорційно зростає кількість правопорушень, скоєних за допомогою інформаційних технологій. Також требо відзначити, що відчувається недостатня обізнаність співробітників поліції в питаннях електронної інформації, причому не лише співробітниками спеціальних підрозділів, таких як кіберполіція, оперативно-технічного забезпечення або кримінального аналізу, а й усіма без винятку суб'єктами оперативно-розшукової діяльності, слідчими та навіть дільничними офіцерами поліції.

Аналіз останніх досліджень і публікацій. До проблеми формування професійних компетентностей майбутніх фахівців у процесі навчання у закладі вищої освіти зверталися: А. Абдулін, В. Бесчастний, С. Вітвицька, В. Ягупов та ін. Зміст терміна «компетенція» окреслили Ю. Фролов, Д. Махотін, А. Хуторський та інші науковці. Окремі аспекти підготовки фахівців у галузі інформаційних технологій для правоохоронних органів розглядалися в наукових працях О. Бандурки, В. Голубєва, В. Грохольського, О. Користіна, О. Корнейко, Е. Рижкова, В. Хахановського, Х. Ярмакі, В. Чернєя та інших. Питання пошуку інформації у відкритих джерелах інформації досліджували С. Албул, М. Грібов, К. Ісмайлов, Я. Кондратьєв, Л. Лефтеров, О. Манжай, В. Носов.

Як зазначає І. Катеринчук, проблемою інформаційного забезпечення правоохоронних органів України $є$ питання підготовки кадрів для цих органів, які 6 поєднували високий рівень знань, умінь та навичок як у правовій сфері, так і у сфері інформаційних технологій. Це пояснюється тим, що підготовка фахівців передбачає підготовку на рівні користувача у сфері інформаційних технологій, чого не досить для ефективної діяльності у сфері інформаційного забезпечення правоохоронних органів, так само, як і основ юридичних знань у фахівців із технічних наук. Спроби ж поєднати під час здобуття вищої освіти всі необхідні знання, уміння та навички через ті чи інші при- чини ще не завершилися однозначно позитивним результатом. Тому вказана проблема все ще очікує свого вирішення [1, с. 45].

Також сучасні тенденції вдосконалення професійної підготовки майбутніх правоохоронців досліджено О. Федоренко у статті «Сучасні тенденції удосконалення професійної підготовки майбутніх офіцерів поліції» [2]. Професор А. Мовчан у статті «Модель підготовки фахівців у галузі інформаційних технологій для органів Національної поліції України» проаналізував методологічні й організаційні аспекти підготовки фахівців у галузі інформаційних технологій для органів Національної поліції України [3, с. 151-158]. Вимоги до майбутніх фахівців у галузі інформаційних технологій для Національної поліції висвітлені В. Кудіновим у статті «Вирішення проблем добору та підготовки кадрів правоохоронців щодо протидії кіберзлочинності» [4]. Особливості спеціалізації «Протидія кіберзлочинності» розглянуто у статті В. Хахановського «Проблеми підготовки кадрів з протидії кіберзлочинності» [5].

3 огляду на вищезазначене розгляд та впровадження в освітній процес підготовки здобувачів вищої освіти в закладах освіти зі специфічними умовами навчання сучасних методів та прийомів пошуку інформації з відкритих джерел є значним потенціалом у розвитку компетентностей правоохоронця. У зв'язку із цим назріла проблема застосування сучасних інформаційних технологій з пошуку оперативно значущої інформації, яка може виражатися в різних форматах цифрового світу (txt, pdf, doc), графічних (jpg), звукових (га) і т.д.

Мета статті - здійснити добір та охарактеризувати відкриті джерела інформації у практично орієнтованій підготовці поліцейських.

Методи дослідження. Застосовані інструменти включали аналіз відповідних теоретичних і методологічних джерел. У процесі дослідження використано низку методів, що відповідають меті роботи, а саме: теоретичний - для вивчення й аналізу навчально-методичної документації, науково-методичної літератури, навчальних програм, посібників, узагальнення інформації для визначення теоретико-методологічних основ дослідження; логічного аналізу - для формулювання основних понять та проведення класифікації; конкретно-історичний - для демонстрації динаміки розвитку застосування інформаційних технологій в освітньому процесі підготовки поліцейських; діалектики - для встановлення змісту й особливостей складових елементів компетенцій поліцейських у сфері інформаційних технологій; емпіричні методи - для узагальнення 
педагогічного досвіду, тестування, спостереження, інтерв'ювання, опитування, обговорення.

Результати дослідження. Установлення факту і обставин правопорушення здійснюється, як правило, шляхом отримання оперативної інформації, що передбачено Законом України «Про оперативнорозшукову діяльність». Указані факти потребують перевірки, що регламентується наказами МBC України, а інформація про методи і засоби належить до категорії державної таємниці. Однак слід зазначити, що перевірку даних та пошук інформації про осіб, подію можна провести без використання засобів і методів ОРД, застосовуючи методи кримінального аналізу, також і у відкритих ресурсах у всесвітній мережі Інтернет.

Кримінальний аналіз - це комплекс методів, які використовуються для збирання, оцінки, аналізу та реалізації інформації під час розслідування кримінальних правопорушень, а також із метою їх використання у розробленні тактичних і стратегічних засад із протидії злочинності [6, с. 53]. Однією з найважливіших частин кримінального аналізу $\epsilon$ пошук і аналіз інформації на підставі відкритих джерел (OSINT). Це концепція, методологія і технологія отримання i використання інформації з відкритих джерел - для підтримки прийняття рішень.

Джерела OSINT розділяють на шість категорій інформаційного потоку, тобто джерел отримання електронної інформації:

- медіа (3MI): друковані газети, журнали, радіо та телебачення;

- мережа (Інтернет): онлайн-публікації, блоги, дискусійні групи, медіа громадян, YouTube та інші відео-хостинги, вікі-довідники та інші вебсайти соціальних медіа (Facebook, Twitter, Instagram та ін.);

- державні дані, публічні урядові звіти, бюджети, слухання, телефонні довідники, прес-конференції, вебсайти та виступи. Оскільки ця інформація походить з офіційних джерел, вона $\epsilon$ публічно доступною і може використовуватися відкрито;

- професійні та академічні публікації, інформація, отримана з журналів, конференцій, симпозіумів, наукових праць та дисертацій;

- комерційні дані, комерційні зображення, фінансові оцінки, бази даних;

- сіра література, технічні звіти, препринти, патенти, робочі документи, ділові документи, неопубліковані роботи та інформаційні бюлетені.

Нині під час збору даних вкрай важливим $\epsilon$ час, за який правоохоронець отримує необхідну йому інформацію, тому отримання іï з відкритих джерел $\epsilon$ дуже ефективним. Отже, спосіб отримання поліцейським оперативно значущої інформації через здійснення пошуку іiі за допомогою чат-ботів у месенджері Telegram є сучасним, яким не можна нехтувати.

Тому більш зосередимо свою увагу на тому, звідкіля нині поліцейський отримує знання. Для цього проаналізуємо навчальні плани та програми підготовки фахівців за спеціальністю 081 «Право» за останні 4 роки на предмет забезпечення набуття в межах загальної компетентності здобувачами вищої освіти навичок використання сучасних інформаційних і комунікаційних технологій та здатністю до пошуку, оброблення й аналізу інформації з різних джерел.

Так, навчальний план підготовки здобувачів вищої освіти за освітнім ступенем «бакалавр» указаної спеціальності Одеського державного університету внутрішніх справ містить такі дисципліни, як: «ннформаційні технології»; «Основи кримінального аналізу»; «ннформаційне забезпечення професійної діяльності»; «нфформаційне право» (з 2019 дисципліна вилучена з навчальних планів).

Відповідно до розвитку залученості інформаційних технологій цілком логічним було б збільшення аудиторних годин навчальних дисциплін, але на прикладі освітнього процесу в Одеському державному університеті внутрішніх справ (така ситуація $\epsilon$ характерною для всіх закладів вищої освіти МВС України) ми бачимо, що в 2016-17 н.р. блок дисциплін, під час вивчення яких формується компетентність здобувачів вищої освіти та набуваються навички використання сучасних інформаційних і комунікаційних технологій та здатність до пошуку, оброблення та аналізу інформації з різних джерел, становить 168 ауд. год., а вже за 4 роки розвитку технологій - зменшуються до 102 ауд. год., тобто мінус 40\% (див. рис. 1).

Тобто за 4 роки блок навчальних дисциплін, які забезпечують набуття навичок використання інформаційних і комунікаційних технологійта здатність до пошуку, оброблення й аналізу інформації з різних джерел, втратив 40\% [7, с. 19-24].

Тому, не зупиняючись на ситуації, що склалася, і розуміючи, що вивчення інформаційних технологій дистанційно не вирішує проблеми отримання здобувачами вищої освіти достатніх практичних знань, та беручи до уваги, як указують окремі науковці (С. Литвинова [8], М. Шишкіна [9]), що для підвищення рівня сформованості ІК-компетентності учасників освітнього процесу варто проводити додаткові факультативи та (або) спецкурси. 


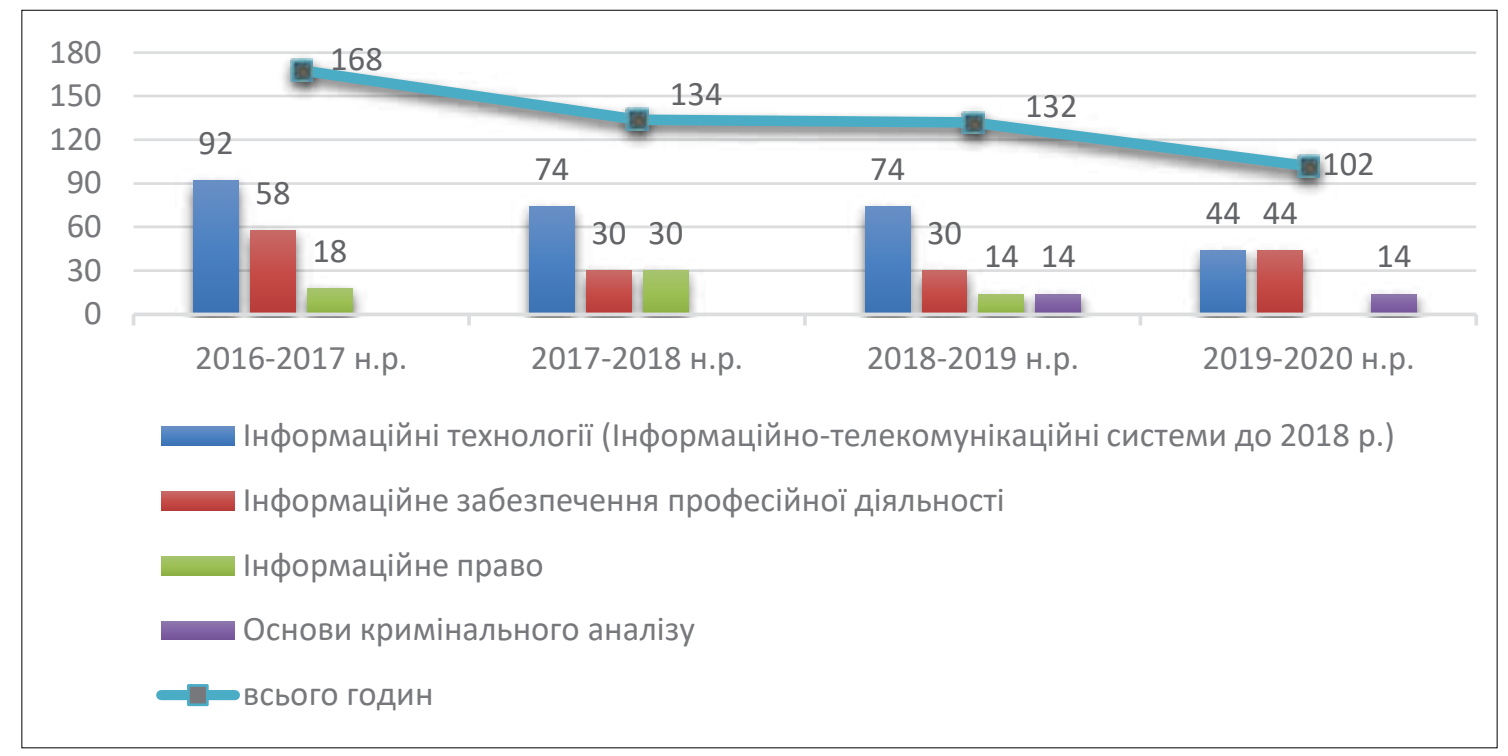

Рис. 1. Динаміка зменшення аудиторних годин за блоком навчальних дисциплін, під час вивчення яких формується компетентність у сфері інформаційних знань

Пропонуємо підхід до вдосконалення освітнього процесу: запровадження тренінгових занять із найбільш практично значущих тем, передбачених тематичними планами навчальних дисциплін із блоку дисциплін, які забезпечують набуття компетентностей з електронної інформації.

Так, у дисципліну «Інформаційні технології» необхідно ввести тренінг для здобувачів вищої освіти поліцейських спеціальностей на тему: «Використання поліцейськими чат-ботів у месенджері Telegram», основні завдання якого:

- забезпечити формування у правоохоронців свідомого та відповідального ставлення до теоретичних і практичних основ використання інформаційних технологій у практичній діяльності;

- сформувати у правоохоронців теоретичні знання та практичні навички використання чат-ботів у месенджері Telegram;

- ознайомити поліцейських із функціональними можливостями чат-ботів як джерел отримання оперативно значущої інформації;

- навчити здобувачів вищої освіти на практиці застосовувати одержані знання з використання чат-ботів;

- сформувати ІК-компетентності здобувачів вищої освіти щодо використання інформаційних технологій у майбутній професійній діяльності.

Так, чат-бот - це комп'ютерна програма, розроблена на основі нейромереж i технологій машинного навчання, яка веде розмову за допомогою слухових або текстових методів [10].

Наведемо деякі чат-боти в Telegram, за допомогою яких кожен співробітник правоохоронних органів швидко зможе отримати потрібну йому інформацію: @OpenDataUABot; @UAFind_bot; @info_baza_bot; @temp_mail_bot; @tavk_bot; @HowToFind_bot; @storebot; @get_kontakt_bot; @mailsearchbot; @whoisdombot.

Розглянемо функціонал @OpenDataUABot - це сервіс моніторингу державних реєстраційних даних компаній, осіб та авто. Для отримання інформації необхідно в пошуковий рядок боту ввести інформацію з перерахованих даних та за декілька секунд отримати відповідь (див. таблицю 1).

@info_baza_bot здійснює пошук інформації про особу за такими параметрами:

- за номером телефону;

- за прізвищем, ім'ям, по батькові;

- за email;

- за автомобільним номером;

- за фото обличчя людини.

Бот під назвою @temp_mail_bot - це генератор тимчасових поштових скриньок, які можна створити у два кліки. Використовується бот для швидкого створення одноразової поштової скриньки.

Бот @tavk_bot надасть миттєво інформацію щодо входу особи до соціальної мережі Вконтакте та покаже, що вхід відбувся з ПК або мобільного пристрою.

@HowToFind_bot являє собою бот-каталог, який містить боти та інші ресурси за такими розділами: Email, Full name, Nickname, Biometrics, Account, Site, License plate, Address, Documents, Phone, Wallet, File, Databases, Searchers.

Аналогічний функціонал у @HowToFind_bot міститься в @storebot, але його відмінністю 
Таблиця 1

Відомості, які необхідно ввести в @OpenDataUABot для отримання відповідної інформації

\begin{tabular}{|l|l|}
\hline \multicolumn{1}{|c|}{ Дані, які вводяться } & \multicolumn{1}{c|}{ Інформація, яка отримується } \\
\hline $\begin{array}{l}\text { Код, назва чи адреса } \\
\text { компанії }\end{array}$ & $\begin{array}{l}\text { Офіційна назва, код, повна адреса реєстрації компанії; П.І.Б. керівника компанії } \\
\text { та всі пов'язані з ним компанії; вид діяльності, дата реєстрації, статутний капітал, } \\
\text { номер телефону, податковий борг компанії; судові справи. }\end{array}$ \\
\hline $\begin{array}{l}\text { П.І.Б. особи українською } \\
\text { мовою }\end{array}$ & $\begin{array}{l}\text { Власником яких компаній, ФОП була та є особа; які є документи у судовому реєстрі, } \\
\text { судові справи; чи є боржником по аліментах. }\end{array}$ \\
\hline Номер паспорта & Находження вказаного паспорта в базах втрачених та анульованих паспортів. \\
\hline $\begin{array}{l}\text { Податковий номер } \\
\text { фізичної особи }\end{array}$ & $\begin{array}{l}\text { Назва компанії, ФОп, повна адреса реєстрації компанії; дата реєстрації, П.І.Б. та дата } \\
\text { народження керівника компанії; номер телефону, вид діяльності, податковий борг, } \\
\text { судові справи, нерухомість компанії. }\end{array}$ \\
\hline $\begin{array}{l}\text { Номер авто чи } \\
\text { техпаспорта }\end{array}$ & $\begin{array}{l}\text { Реєстрацію та дані авто (модель, рік випуску, дата реєстрації, колір, об’єм двигуна, } \\
\text { вага, тип авто, тип кузова, vіп-код); ліцензія на перевезення; інші авто власника. }\end{array}$ \\
\hline Номер судової справи & Конкретне посилання на судову справу. \\
\hline
\end{tabular}

$\epsilon$ загальний каталог ботів, тобто більшість ботів у ньому використовується не для оперативних цілей. Але як бот-каталог для пошуку нових ботів $\epsilon$ незамінним. Так, @storebot має такі розділи: ігри; розваги; соціальні; фото та відео; новини, інструменти; для дорослих; broadcast.

@get_kontakt_bot здійснює за номером телефону пошук та видає інформацію про П.І.Б. користувача. Бот працює тільки з номерами: KZ, RU, BY, KG, UA формату.

@mailsearchbot. За номером телефону або email надає пароль до електронної скриньки.
Добре працює з поштовими сервісами Mail.ru та Yandex. Як повідомляють розробники боту, станом на червень 2019 р. у базі бота знаходяться приблизно 9 млрд записів у зв'язці логін та пароль та ще більш 3 млрд чекають на завантаження [16].

@whoisdombot. Зручний бот для отримання whois-інформації доменів та IP.

@smart_searchbot. Допомагає знайти додаткову інформацію стосовно номера телефону, id ВКонтакте, email та свій id Telegram. Недоліком $€$ ліміт запитів, продовження яких $€$ платним (див. таблицю 2).

Стислий опис та посилання на чат-боти, які використовуються для отримання оперативно значущої інформації

\begin{tabular}{|c|c|c|}
\hline Назва, логотип & Опис чат-боту & Посилання (QR-код) \\
\hline 1 & 2 & 3 \\
\hline @OpenDataUABot & $\begin{array}{l}\text { Сервіс моніторингу реєстраційних даних компаній, } \\
\text { судового реєстру та реєстрації авто. } \\
\text { Здійснює пошук за кодом ЄДРПОУ, назвою компанії, } \\
\text { П.І.Б. директора чи адресою та номером автомобіля. }\end{array}$ & \\
\hline @info_baza_bot & $\begin{array}{l}\text { Здійснює пошук за номером телефону, за П.І.Б., } \\
\text { за еmail, за авто, а також фото. }\end{array}$ & \\
\hline @tempmailbot & $\begin{array}{l}\text { Генератор тимчасових поштових скриньок. Вико- } \\
\text { ристовується якщо потрібно зробити кілька одноразо- } \\
\text { вих акаунтів. }\end{array}$ & \\
\hline
\end{tabular}


Закінчення таблиці 2

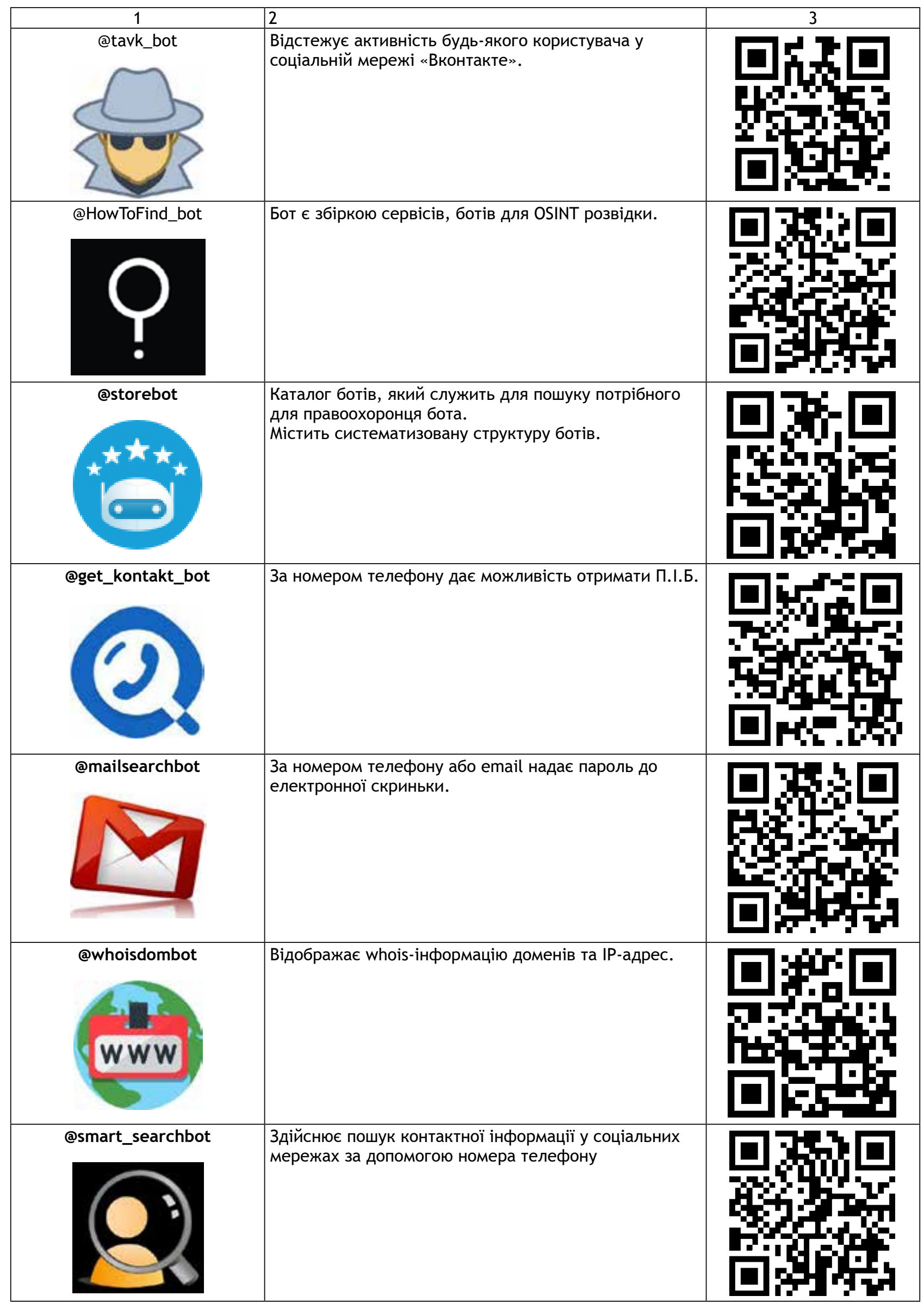


Слід зауважити, що наявні боти-каталоги, в яких постійно з'являються нові боти, які можуть допомагати правоохоронцям, тому у разі викладання дисципліни викладачу необхідно на них також зосереджувати увагу як засобу для майбутнього вивчення [7, с. 19-24].

Висновки. Проведено аналіз практично орієнтованої підготовки здобувачів вищої освіти за галузями знань 08 «Право», 26 «Цивільна безпека» та відповідно спеціальностями 081 «Право», 262 «Правоохоронна діяльність», 125 «Кібербезпека», 124 «Системний аналіз» у закладах вищої освіти зі специфічними умовами навчання, які здійснюють підготовку поліцейських, на предмет забезпечення набуття здобувачами вищої освіти в межах загальної компетентності навичок використання сучасних інформаційних і комунікаційних технологій та здатністю до пошуку, оброблення й аналізу інформації з різних джерел. Це дало можливість визначити, що сталість освітнього процесу, зменшення аудиторних годин блоку навчальних дисциплін, які відповідають за набуття зазначених компетентностей та стрімкий розвиток технологій, суттєво впливає на рівень сформованості ІК-компетентності здобувачів вищої освіти, отже, доцільно для вдосконалення освітнього процесу впроваджувати тренінг на тему: «Застосування поліцейськими чат-ботів у месенджері Telegram", який забезпечить отримання навичок з використання чат-ботів у месенджері Telegram, у тому числі у дистанційному навчанні бакалаврів та магістрів зазначених спеціальностей.

3 усього розмаїття відкритих ресурсів для пошуку оперативно значущої інформації здійснено добір чат-ботів у месенджері Telegram, які доцільно використовувати поліцейськими, а саме: @OpenDataUABot, @info_baza_bot, @temp_mail_ bot, @tavk_bot, @HowToFind_bot, @storebot; @ get_kontakt_bot, @mailsearchbot; @whoisdombot, @smart_searchbot. Кожному 3 перерахованих чат-ботів надано характеристику, виокремлено переваги використання та на прикладах наведено конкретний алгоритм дій особи, яка здійснює пошук.

Уважаємо, що в навчальному процесі доцільно формувати як у майбутніх правоохоронців, так і діючих поліцейських під час підвищення кваліфікації навички пошуку інформації у відкритих джерелах загалом та вміння роботи з чат-ботами в месенджері Telegram зокрема. 3 урахуванням швидкого розвитку технологій також необхідно приділяти увагу розвитку в поліцейських потреби в постійному пізнанні, що значно підвищить ефективність їхньої роботи.

\section{Література}

1. Катеринчук І.П. Інформаційне забезпечення діяльності правоохоронних органів України: проблеми теорії і практики : монографія. Київ. 2014. 392 с.

2. Федоренко О. Сучасні тенденції удосконалення професійної підготовки майбутніх офіцерів поліції. Новий колегіум. № 4. 2016. С. 42-52.

3. Мовчан А.В. Модель підготовки фахівців у галузі інформаційних технологій для органів Національної поліції України. Інформаційні технології $і$ засоби навчання. Том 66. № 4. 2018. С. 149-159.

4. Кудінов В.А. Вирішення проблем добору та підготовки кадрів правоохоронців щодо протидії кіберзлочинності. Кадровий вісник. № 1. 2011. С. 51-68.

5. Хахановський В.Г. Проблеми підготовки кадрів з протидії кіберзлочинності. Митна справа. № 2 (74), ч. 2. 2011. С. 305-307.

6. Короткий тлумачний словник керівника підрозділу кримінального аналізу : словник / Ісмайлов К.Ю., Кіреєва О.С., Половніков В.В., Постол О.І., Фаріон О.Б. Одеса : Одеський державний університет внутрішніх справ. 2018. 110 с.

7. Ismailov K.Y. Training of police officers to search and analize significant information from open sources (example of chat-bott applications). Sciences of Europe (Praha, Czech Republic). Vol. 5, No. 48 (2020). P. 17-25.

8. Литвинова С.Г. Теоретико-методичні основи проєктування хмаро орієнтованого навчального середовища загальноосвітнього навчального закладу : дис. ... доктора пед. наук : 13.00.10. ІІн-т інформаційних технологій і засобів навчання НАПН України, Київ, 2016.

9. Шишкіна М.П. Теоретико-методичні засади формування і розвитку хмаро орієнтованого освітньо-наукового середовища вищого навчального закладу : дис. докт. пед. наук : 13.00.10. Ін-т інформаційних технологій і засобів навчання НАПН України, Київ, 2016.

10. Чат-бот. URL: https://uk.wikipedia.org/wiki/\% D0\%A7\%D0\%B0\%D1\%82-\%D0\%B1\%D0\%BE\%D1\%82.

Білоконь Д. С., аспірант

одеського державного університету внутрішніх справ

Пишна А. Г., кандидат юридичних наук, доцент кафедри адміністративної діяльності поліціі Одеського державного університету внутрішніх справ 